\title{
Brand Embarrassment: Antecedents and Outcomes Variables
}

\author{
Paterne Micha MBELANGANI MBAN, Sevtap ÜNAL \\ Katip Çelebi University \\ E-mail address_mbanpaterne@gmail.com
}

\begin{abstract}
The present study aimed to investigate the role of negative feelings on the consumer buying decision. The influence of a brand image, the need for social approval, and negative brand selfexpressiveness on brand embarrassment, as well as the influence of embarrassment on brand hate and brand detachment, mediated by interpersonal influence, were investigated. Findings revealed that brand image and the need for social approval do not have any influence on brand embarrassment, while the negative brand self-expressiveness does predict brand embarrassment. On the other side, the findings revealed that brand embarrassment creates brand hate and brand detachment. And, interpersonal influence has a mediating role in the relationship between brand image-brand detachment, negative brand self-expressiveness-brand hate, and negative brand selfexpressiveness-brand detachment.
\end{abstract}

Keywords: Brand Embarrassment, Brand Hate, Brand Detachment, Brand Image, Need for Social Approval, Negative Brand Self-Expressiveness, Interpersonal Influence.

\section{INTRODUCTION}

This is an open access article under the CC-BY-NC license.

Since the early 1980s, research into consumer behavior has shown a growing interest regarding the concept of emotion. Holbrook and Hirschman (1982) also wanted research to finally conceptualize emotions because they see them as a key dimension of purchasing behavior. Moreover, it was found from several studies that emotions are important components of consumer behavior (Holbrook, Chestnut, Oliva, Greenleaf, 1984). Murray (2013), in his research on fMRI neuroimagery, showed that when assessing brands, consumers firstly refer to feelings (personal emotions and experiences) rather than brand information such as its characteristics, attributes, and realities. Emotional marketing aims to reinforce this emotional aspect, which promotes action. Thus, several studies have focused on the positive role of emotions like love, loyalty, attachment, and so on. However, a limited number of studies focused on the study of negative emotions such as hate, embarrassment, and guilt generated by an advertising stimulus. Even though it is well known that emotions significantly influence the buying behavior of the consumer (Wakefield and Baker, 1998), not much is known about the effects of embarrassment. Therefore, this research aims at investigating the effect of brand embarrassment on both brand hate and brand detachment by mitigating the impact of brand image, the need for social approval, and the negative brand self-expressiveness on brand embarrassment. 


\section{LITERATURE REVIEW}

\section{Brand Embarrassment}

Embarrassment is a painful but important emotional state. Most researchers believe that its purpose is to make people feel bad about their social or personal mistakes as a form of internal (or societal) feedback so that they learn not to repeat the error (Psychology Today, 2020). Neel Burton MD (2014) defines it "as the feeling of discomfort experienced when some aspect of ourselves is, or threatens to be, witnessed by or otherwise revealed to others, and we think that this revelation is likely to undermine the image of ourselves that we seek to project to those others" (Christine Harris, 1999).

The emphasis on embarrassment in this study is because humans also express negative feelings towards brands (Ian Grant and Gianfranco Walsh,2009; Yiting Li, Defeng Yang, Han Zhou, 2018). Brand embarrassment is defined as anxiety and negative emotions resulting from brands in certain consumption contexts. Generally, this manifests itself when a consumer feels a sense of discomfort with the perception of being negatively judged by others because of the consumer's association with a brand having embarrassing attributes (Walsh et al. .2016; Grant and Walsh 2009; Dahl et al. .2001; Tsao and Chan 2011; Miller 1995; Lunardo and Mouangue, 2019). Hence, once embarrassed, a consumer or individual is more willing to adopt new measures to diminish the embarrassment. Based on the literature, the following hypotheses are formulated:

H1a: Brand embarrassment influences brand hate.

H1b: Brand embarrassment influences brand detachment.

Brand Image

Brand image is the fundamental and most basic aspect of how a brand is perceived. According to Lambin (1999), the brand image represents all the mental, cognitive and emotional representations that a person or group of people have about a brand (Keller, 1993). If a consumer has a positive perception of it, she/he will be more likely to consume the brand. The more positively a brand's image is perceived, the more people trust it and recognize the brand as one of the leaders in its sector, therefore more visible it will become (Alexandre Bonnisseau, 2017). In contrast, if a consumer has a negative perception of a brand, she/he is likely to avoid the brand. This avoidance may be the result of embarrassment, which in turn can result in brand detachment by the consumer in favor of another brand for the same category of products.

$\mathrm{H} 2$ : Brand image affects brand embarrassment.

Need for social approval

The need for social approval is a concept that makes people consider other people's expectations and judgments important in social interactions and when making decisions. By definition, the need for social approval indicates a desire to conform, a concern for others' opinions, and an urge to be socially acceptable. People with a higher need for social approval care more about what others think (J, M. Twenge, and Charles, 2007).

The approval motive is how people feel about being accepted in society and what may or may not be approved by social standards. In other words, people want to feel sanctioned and not rejected. This understanding can affect the decisions and lifestyles of individuals, especially in social life. The idea that "If I fail" that leads to exam anxiety, I will be humiliated by others can also be seen as a reflection of the need for social approval (Karaşar. B \& Öğülmüş. S, 2016). Based on the literature, the following hypothesis is made.

H3: The need for social approval affects brand embarrassment.

Negative brand social self-expressiveness

Particularly, the brand self-expressiveness refers to the adequacy between the brand and the person and concerns the self-concept of an individual and how the brand allows her/him to express herself/himself to others (Cronje et al. 2016; Escalas and Bettman, 2005). Through the consumption 
of certain brands, consumers can describe how their brand consumption is consistent with a group of consumers to which they belong (Chernav et al., 2011; Escalas and Bettman, 2005).

A person is likely to feel embarrassed by a brand if he thinks that the brand projects a negative or undesirable social self (Grant and Walsh, 2009; Walsh et al. 2016). Therefore, negative brand social self-expressiveness is likely to predict brand embarrassment.

H4: Negative brand social self-expressiveness is likely to predict brand embarrassment.

Brand Hate

Hate towards a brand implies strong negative emotions from the consumer (Romani and al, 2009). It is important to note that these negative emotions against a brand can occur even in the absence of purchase, resulting from a negative attitude towards a marketing stimulus (Romani, Dalli \& Gistri, 2006; Lee, Motion \& Conroy, 2007).

Brand hate can be defined as the extreme negative emotional component of attitude towards a brand attitude (Bryson et al., 2013). These emotions are characterized by different levels of intensity, ranging from simple aversion to hate, which is likely to result in anger, irritation, indignation, and resentment. This will lead to a decrease in the willingness to buy, brand switching, negative word of mouth, and brand avoidance (Sternberg, 2003). Therefore, any behavior that can have a direct effect on financial losses to the company. The same behavioral reactions similar to brand hate relationships are expected in this study.

H5: Brand embarrassment affects brand hate

\section{Brand detachment}

Brand detachment is one of the marketing concepts that have been developed to explain the dissolution of the relationship between the consumer and the brand. Perrin-Martinenq (2004) defines brand detachment as "the psychological state of distance concerning a brand, resulting from the weakening or the dissolution of the affective bond existing between the consumer and the brand." The detachment can be progressive or brutal, characterizing itself in loss of interest in a brand, in which the cognitive benefit, sense, or affective resonance are no longer perceived voluntarily or involuntarily in the event of progressive deterioration by the consumer. It can naturally be painful, the stronger the psychological bond that linked the consumer to the brand. Therefore, once a consumer feels embarrassed by a brand, the latter may choose between partial and total detachment strategies. Thus, the following hypothesis is formulated.

H6: Brand embarrassment affects brand detachment.

Interpersonal Influence

Several psychological research and consumer research have shown that interpersonal influence is an important determinant of an individual's behavior, and has also highlighted the existence of interpersonal influence on an individual's decision-making process (Cohen and Golden 1972; Moscovici 1985).

Bearden et al. (1989) define interpersonal influence as the need to identify with or enhance one's image in the opinion of others through the acquisition and use of products and brands, the willingness to conform to the expectations of others regarding the buying decisions, and/or the tendency to learn about products and services by observing others or seeking information from others. Interpersonal influence is then, a type of social influence that results from compliance encouraging or forcing group members while discouraging, and perhaps punishing, non-compliance. It is one of the three types of social influences that lead people to conform to majority norms or group norms (Burnkrant and Cousineau 1975; Deutsch and Gerard 1955). Therefore, based on this, the following hypotheses are formulated.

H7a: Interpersonal influence mediates the relationship between brand image and brand hate

$\mathrm{H} 7 \mathrm{~b}$ : Interpersonal influence mediates the relationship between brand image and brand detachment, 
H7c: Interpersonal influence mediates the relationship between the need for social approval and brand hate,

H7d: Interpersonal influence mediates the relationship between the need for social approval and brand detachment,

H7e: Interpersonal influence mediates the relationship between the negative brand selfexpressiveness and brand hate,

H7f: Interpersonal influence mediates the relationship between negative brand selfexpressiveness and brand detachment.

\section{RESEARCH METHODOLOGY}

\section{Purpose of the study}

The purpose of this study is to investigate both the predictor and outcome variables of embarrassment; and also the mediating role of interpersonal influence between those variables. Among the factors leading to brand embarrassment, brand image, need for social approval, and the negative brand social self-expressiveness were identified in this study. Brand hate and brand detachment were identified as outcomes of brand embarrassment.

\section{Sample}

The research data was collected via a survey targeting 137 respondents from İzmir Katip Çelebi University in Turkey.

\section{Measurements}

Various scales that have been developed and applied in previous studies to measure variables were selected and used. Brand image is measured by using the scale of Aaker, D.A. (1996), need for social approval using Karaşar, B., \& Öğülmüş, S. (2016), negative brand social self-expressiveness using the scale of Carroll and Ahuvia (2006); brand hate using the scale of Zarantonello et al. (2016), brand detachment using the scale of Perrin-Martinenq, (2014), brand embarrassment using the scale of Walsh et al. (2016), and interpersonal influence using the scale of Bearden, Netemeyer, and Teel (1989). Also, the Likert 5-point scale (1. strongly disagree; 5. strongly agree) was used to rate the variables. SPSS 24 and AMOS 23 were used to analyze data.

\section{Research Model}

Taking into account the purpose of this research and the theoretical information, the research model is determined as in Figure 1.

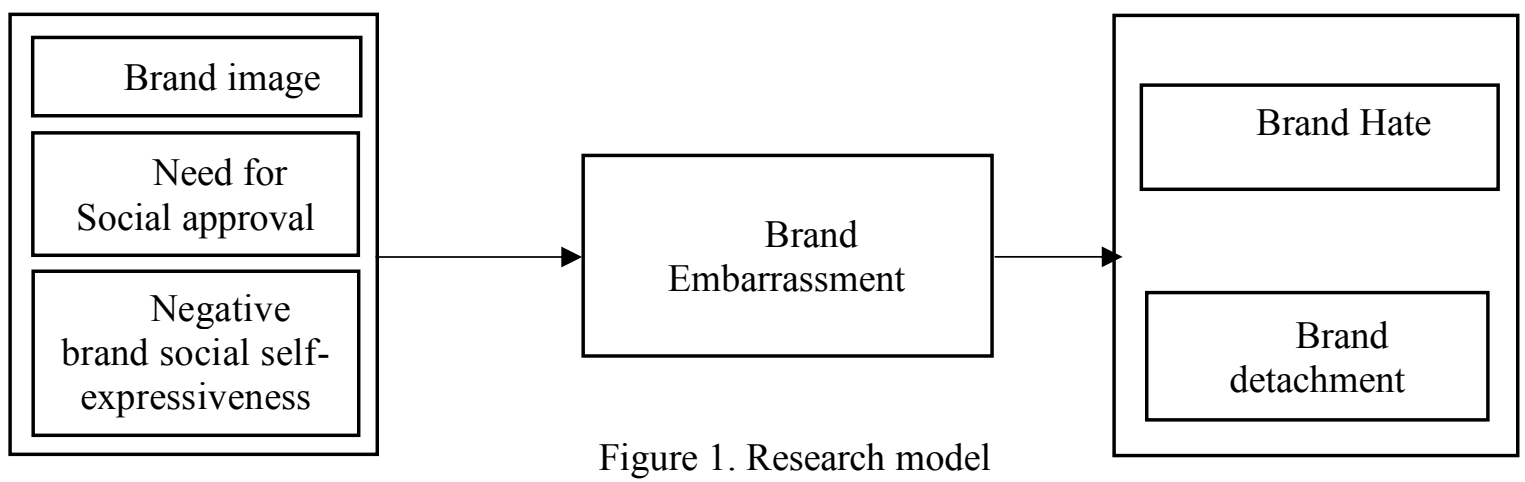




\section{ANALYSIS AND RESULTS}

\section{Sample Characteristics}

The demographics of the sample are shown in Table 1.

Table 1. Demographic Characteristics

\begin{tabular}{|c|c|c|c|c|c|}
\hline Gender & Frequency (f) & $(\%)$ & Age & Frequency (f) & $(\%)$ \\
\hline Male & 51 & 62,8 & $18-28$ & 130 & 94,9 \\
\hline Female & 86 & 37,2 & 29-39 & 5 & 3,6 \\
\hline $\begin{array}{l}\text { Monthly } \\
\text { Income } \\
\text { (Jobless } \\
\text { students) }\end{array}$ & Frequency (f) & $(\%)$ & $40-50$ & 2 & 1,5 \\
\hline $\begin{array}{c}2000 \mathrm{TL} \\
\text { and below }\end{array}$ & 113 & 83,1 & Education Level & Frequency (f) & $(\%)$ \\
\hline $\begin{array}{c}2001-3000 \\
\text { TL }\end{array}$ & 9 & 6,6 & $\begin{array}{c}\text { Secondary } \\
\text { school }\end{array}$ & 2 & 1,5 \\
\hline $\begin{array}{c}3001-4000 \\
\text { TL }\end{array}$ & 8 & 5,9 & Undergraduate & 126 & 92,0 \\
\hline $\begin{array}{c}4001-5000 \\
\text { TL }\end{array}$ & 1 & 0,8 & Graduate & 7 & 5,1 \\
\hline $\begin{array}{c}5001-6000 \\
\text { TL }\end{array}$ & 3 & 2,2 & $\mathrm{PhD}$ & 2 & 1,5 \\
\hline $\begin{array}{c}6001 \mathrm{TL} \\
\text { and above }\end{array}$ & 2 & 1,4 & Total & 273 & 100 \\
\hline $\begin{array}{l}\text { Marital } \\
\text { Status }\end{array}$ & Frequency (f) & $(\%)$ & & & \\
\hline Married & 4 & 2,9 & & & \\
\hline Single & 133 & 97,1 & & & \\
\hline
\end{tabular}

Table 2 shows the main reasons why respondents feel embarrassed by a brand.

Table 2. Main Reasons for Embarrassment

\begin{tabular}{|c|c|c|}
\hline & Frequency & Percent \\
\hline Price & 16 & 11,7 \\
\hline Quality & 66 & 48,2 \\
\hline Stability & 19 & 13,9 \\
\hline Convenience & 1 & 0,7 \\
\hline Style & 3 & 2,2 \\
\hline Personal & 2 & 1,5 \\
\hline Performance & 23 & 16,8 \\
\hline Image & 6 & 4,4 \\
\hline Others & 1 & 0,7 \\
\hline Total & 137 & 100,0 \\
\hline
\end{tabular}


As seen in Table 3, product "quality" appears as the main reason why respondents felt embarrassed with a brand. Product performance comes as the second reason, followed by product stability and price.

\section{TESTING THE RESEARCH MODEL}

\section{Reliability and Validity of the Scales Used in the Research}

In order to make reliability analysis, the Cronbach's alpha (Table 4). As seen in Table 4, Cronbach's alpha is higher than the accepted value for all variables.

Table 3. Reliability and Validity of the Scales Used in the Research

\begin{tabular}{|l|c|}
\hline \multicolumn{1}{|c|}{ Variables } & Cronbach's alpha \\
\hline Brand Image & 0,842 \\
\hline Need for Social Approval & 0,884 \\
\hline Negative Brand Self-Expressiveness & 0,856 \\
\hline Interpersonal Influence & 0,864 \\
\hline Brand Embarrassment & 0,857 \\
\hline Brand Hate & 0,778 \\
\hline Brand Detachment & 0,877 \\
\hline
\end{tabular}

During the conformity factor analysis some modifications were done and after modifications suggested for goodness of fit and acceptable values were obtained: Chi-square/Sd: 1,195 RMSEA: 0.038, GFI: 0.833, AGFI: 0.798, NFI: 0.956, NNFI: 0.956, CFI: 0.96).

Table 5. The validity of Conformity Factor Analysis

\begin{tabular}{|c|c|c|c|l|l|l|l|l|l|l|}
\hline & CR & AVE & MSV & MaxR(H) & NBSSE & NFSA & BH & BD & BE & BI \\
\hline NBSSE & 0,860 & 0,608 & 0,472 & 0,875 & 0,780 & & & & & \\
\hline NFSA & 0,885 & 0,418 & 0,160 & 0,899 & 0,173 & 0,646 & & & & \\
\hline BH & 0,779 & 0,541 & 0,305 & 0,787 & 0,539 & 0,059 & 0,736 & & & \\
\hline BD & 0,885 & 0,722 & 0,271 & 0,963 & 0,333 & 0,054 & 0,521 & 0,850 & & \\
\hline BE & 0,796 & 0,526 & 0,472 & 0,895 & 0,687 & 0,118 & 0,552 & 0,233 & 0,726 & \\
\hline BI & 0,843 & 0,575 & 0,160 & 0,852 & 0,011 & 0,400 & 0,195 & 0,153 & 0,130 & 0,758 \\
\hline
\end{tabular}

\section{Structural Model Test}

The goodness of fit indices showed that the model fits well with the data (Chi-square: 18.304, df: 6, Chi-square/Sd: 3.051, RMSEA: 0.13, GFI: 0.96, AGFI: 0.82, NFI: 0.91, PClose: 0.030, CFI: 
0.93). The results of the structural equation model examining the effect of a brand image need for social approval and negative brand self-expressiveness on brand embarrassment; and also, the effect of brand embarrassment on brand hate and brand detachment is shown in table 6 .

Table 6. Research Results

\begin{tabular}{|c|c|c|l|l|c|}
\hline Relationships & $\begin{array}{c}\text { Standard } \\
\text { Value }\end{array}$ & $\begin{array}{c}\text { Error } \\
\text { Value }\end{array}$ & $\Gamma$ Value & $\mathrm{P}$ & $\mathrm{R}^{2}$ \\
\hline $\begin{array}{c}\text { Brand Image-Brand } \\
\text { Embarrassment }\end{array}$ & $-0,02$ & 0,100 & $-0,289$ & 0,773 &, 279 \\
\cline { 1 - 4 } NFSA- Brand Embarrassment & 0,28 & 0,360 & 0,780 & 0,436 & \\
\cline { 1 - 4 } NBSE- Brand Embarrassment & 0,64 & 0,092 & 6,944 & 0,001 &, 059 \\
\hline $\begin{array}{c}\text { Brand Embarrassment - Brand } \\
\text { Hate }\end{array}$ & 0,63 & 0.091 & 7,020 & 0,001 &, 265 \\
\hline $\begin{array}{c}\text { Brand Embarrassment -Brand } \\
\text { Det. }\end{array}$ & 0.25 & 0,099 & 2,617 & 0,004 & \\
\hline
\end{tabular}

As seen in Table 6, the p-value for the brand image is 0.773 , the need for social approval is 0.436 , the negative brand self-expressiveness is 0,001 , and brand embarrassment is 0,001 . Therefore, brand embarrassment is explained by negative brand self-expressiveness; and also, brand hate and brand detachment are explained by brand embarrassment. Consequently, hypotheses $\mathrm{H} 2$ and $\mathrm{H} 3$ are rejected; H4, H1a, and H1b are accepted.

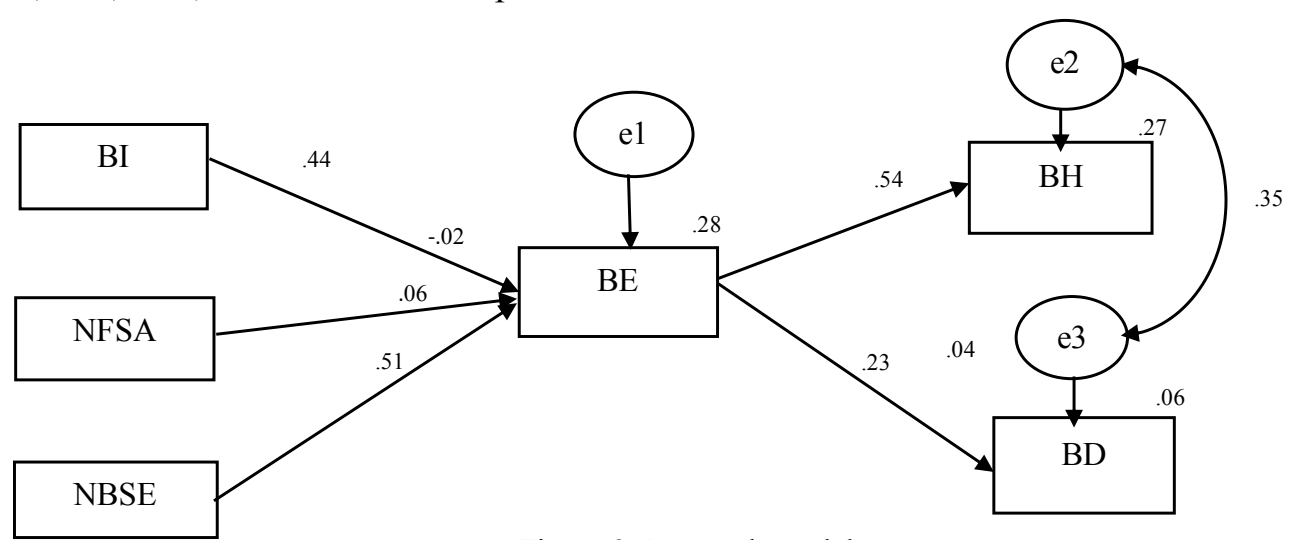

Figure 2: Research model

*BI= Brand Image; NFSA= Need for Social Approval; NBSE= Negative Brand Self-Expressiveness; $\mathrm{BE}=$ Brand Embarrassment; $\mathrm{BH}=$ Brand Hate; $\mathrm{BD}=$ Brand Detachment.

\section{Analysis of the Mediating Effect}

Table 7 shows the mediating role of interpersonal influence. 
Table 7. The results of the mediating effect of interpersonal influence

\begin{tabular}{|c|c|c|c|}
\hline Relationships & $\begin{array}{c}\text { Direct without } \\
\text { mediating }\end{array}$ & Direct with mediating & Indirect \\
\hline BI-IPI-BH & $\begin{array}{c}-, 151(\mathrm{CR}:-1,993 ; \\
\mathrm{NS})\end{array}$ &,$- 156(\mathrm{CR}:-1,895 ; \mathrm{NS})$ & NS No mediation \\
\hline BI-IPI-BD & $\begin{array}{c}-, 169(\mathrm{CR}:-1,981 ; \\
\mathrm{NS})\end{array}$ & $\begin{array}{c}-, 214(\mathrm{CR}:-2,436 ; \\
0,015)\end{array}$ & 0,041 Partial \\
\hline NFSA-IPI-BD &, $027(\mathrm{CR}: 314 ; \mathrm{NS})$ &,$- 049(\mathrm{CR}:-, 510 ; \mathrm{NS})$ & NS No mediation \\
\hline NFSA-IPI-BH &, $004(\mathrm{CR}: 058 ; \mathrm{NS})$ &, $010(\mathrm{CR}:, 106 ; \mathrm{NS})$ & NS No mediation \\
\hline NBSE-IPI-BH & $\begin{array}{c}, 230(\mathrm{CR}: 2,768 ; \\
0,006)\end{array}$ &, $240(\mathrm{CR}: 3,197 ; 0,001)$ & NS No mediation \\
\hline NBSE-IPI-BD & $\begin{array}{c}, 277(\mathrm{CR}: 2,958 ; \\
0,003)\end{array}$ &, $304(\mathrm{CR}: 3,789 ; * * *)$ & NS No mediation \\
\hline
\end{tabular}

As seen in Table 7, interpersonal influence does not have a mediating effect on the relationship between brand image-brand hate, need for social approval-brand hate, need for social approval-brand detachment. However, it has a mediating effect on the relationships between brand image- brand detachment, negative brand self-expressiveness-brand hate, and negative brand self-expressivenessbrand detachment. When interpersonal influence is not added to the model, the effect of negative brand self-expressiveness on both brand hate and brand detachment is respectively 0.230 and 0,277. When adding interpersonal influence to the model, this effect increases respectively to 0.240 and 0,304 for brand hate and brand detachment. Therefore, the interpersonal influence has a partial mediating effect, as seen in Table 7. Interpersonal influence increases negative emotions like brand hate and embarrassment. Based on the findings, $\mathrm{H} 7 \mathrm{~b}, \mathrm{H} 7 \mathrm{e}$, and $\mathrm{H} 7 \mathrm{f}$ are accepted, while $\mathrm{H} 7 \mathrm{a}, \mathrm{H} 7 \mathrm{c}$, and $\mathrm{H} 7 \mathrm{~d}$ are rejected. The final research model is shown in figure 3. 


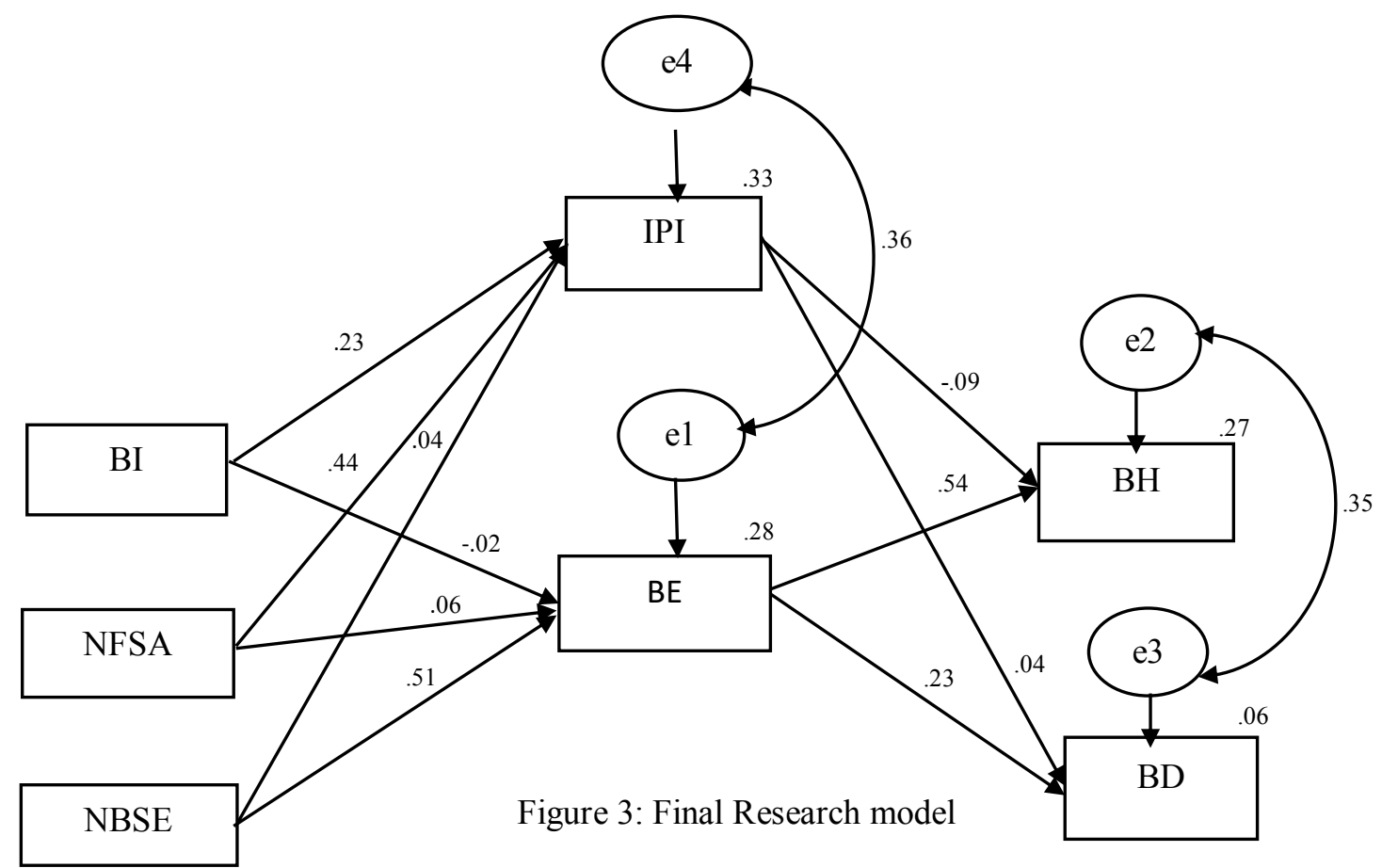

*BI= Brand Image; NFSA= Need for Social Approval; NBSE= Negative Brand Self-Expressiveness; $\mathrm{IPI}=$ Interpersonal Influence; $\mathrm{BE}=\mathrm{Brand}$ Embarrassment; $\mathrm{BH}=$ Brand Hate; $\mathrm{BD}=$ Brand Detachment

\section{DISCUSSIONS AND CONCLUSIONS}

The present study investigated the predictor and outcome variables of brand embarrassment. Findings from the structural model equation revealed that among the predictor variables of brand embarrassment, brand image and the need for social approval do not have any influence on brand embarrassment, while the negative brand self-expressiveness does predict brand embarrassment. As outcome variables, the research results showed that brand embarrassment creates brand hate and brand detachment.

This finding is consistent with the literature of Walsh et al. (2016), which argued that individuals are likely to feel embarrassed by a brand if they think that the brand projects a negative or undesirable social self because individuals are willing to like a brand that would create a social self-desirable in the eyes of others (Carroll and Ahuvia 2006; Wallace et al. 2014). Therefore, the most important thing to point out in this research is that the negative brand self-expressiveness has a strong explanatory effect on brand embarrassment. This finding is in line with the research of Sarkar and Sarkar (2017), which revealed that when a consumer feels embarrassed by a brand, that latter seems less willing to consume the brand publicly. Furthermore, the findings revealed that brand embarrassment creates brand hate and brand detachment. This finding is consistent with prior research conducted by Abhigyan Sarkar et al. (2018), according to which the negative brand social self-expressiveness results in brand hate. Although this finding has not been confirmed in previous research, it has also been found that brand embarrassment creates brand detachment. Considering the mediating effect of the interpersonal influence in this research, it was found to have a partial mediating role. 


\section{Implications}

This study is significant for companies that produce brands that are considered embarrassing. The research findings revealed that a consumer is likely to feel embarrassed by a brand if he/she thinks that the brand projects a negative or undesirable social-self. Thus, companies must focus on consumers who score low on negative brand self-expressiveness, the need for social approval, and high on brand image. Consumers with a lower score on the need for social approval will not be influenced by the hate towards the embarrassing brand. Therefore, consumers will keep on using the brand, avoiding then the detachment effect because these people care less about what others think about them since consumers with a tendency to ignore social approval and having a strong emphasis on their self-image will decrease the indirect effect of social approval on brand hate and brand detachment through brand image and a positive-negative brand self-expressiveness. The research results also brought to light that interpersonal influence is one of the key elements in the relationship between the predictor and outcome variables of brand embarrassment. In that respect, companies should promote or focus on enhancing their image with marketing advertisements.

Also, if companies must compete with embarrassment through their image, the first thing to do is to measure brand image as accepted by consumers. Understanding the factors affecting a company's image and consumer behavior can help managers to develop more competitive strategies. The second step should be to learn how they need for social approval and negative brand selfexpressiveness are shaped and what must be done to change them. In this respect, building a strong brand image provides not only financial but also non-financial benefits for managers and the company itself.

\section{Limitations and Future Research}

This study has some limitations. First, this research only surveyed one particular university students as respondents. In order to make the results more general, the research model should be tested with more respondents. Other limitations concern the small sample size of participants, time, and data accessibility. Moreover, even though the research focused on brand embarrassment, a specific brand or product was not proposed. Also, the research surveyed university students; however, it did not take into account their origins. Therefore, further studies may emphasize the respondents' origins because participants may respond according to their culture.

This study can be used to conduct further studies. Further studies can examine the effect of brand embarrassment on different variables such as customer loyalty, intention to buy or to recommend, and so on.

\section{REFERENCES}

Aaker, D.A. (1996b), "Measuring brand equity across products and markets" , California Management Review, Vol. 31, May, pp. 191 - 201.

Alexandre Bonnisseau, (2017) ; L'importance d'une image de marque, Inbound Marketing

Allen C.-T., K.-A. Machleit et S. Schultz Kleine (1992), A Comparison of Attitudes and Emotions as Predictors of Behavior at Diverse Levels of Behavioral Experience, Journal of Consumer Research, 18, 4, 493-504.

Bearden, Netemeyer, and Teel (1989). Interpersonal Influence: Consumer Susceptibility to Interpersonal Influence, Journal of Consumer Research, Volume 15, Issue 4, March 1989, Pages 473-481

Burnkrant, Robert E., and Alain Cousineau. (1975). "Informational and Normative Influence in Buyer Behavior." Journal of Consumer Research, 2, 206-215.

Carroll, B.A., and A.C. Ahuvia. (2006). Some antecedents and outcomes of brand love. Marketing Letters 17(2): 79-89. 
Cohen, Joel B. and Ellen Golden (1972), "Informational Social Influence and Product Evaluation," Journal of Applied Psychology, 56 (February), 54-59.

Derbaix C. et M.-T. Pham M. (1989), Pour un développement des mesures de l'affectif en marketing : synthèse des prérequis, Recherche et Applications Marketing, 4, 4, 71-87.

Deutsch, Morton, and Harold B. Gerard. (1955). "A Study of Normative and Informational Influence Upon Individual Judgment." Journal of Abnormal and Social Psychology, /(November), 1-15.

Ford, Jeffry D. and Elwood Ellis (1980), "A Re-examination of Group Influence on Member Brand Preference," Journal of Marketing Research, 17 (February), 125-132.

Goldberg, Gerald Gorn, and Richard W. Pollay (Eds.), Advances in Consumer Research (Vol. 17, pp. 770-776). Provo, UT: Association for Consumer Research.

Hair, J. F., Anderson, R. E., Tatham, R. L. and Black, W. C. (1998). "Multivariate Data Analysis", 5th. NY: Prentice Hall International.

Holbrook M.-B. et E.-C. Hirschman (1982), The Experiential Aspects of Consumption: Consumer Fantasies, Feelings and Fun, Journal of Consumer Research 2(9): 132-140

Holbrook, M. B., Chestnut, R. W., Oliva, T. A., \& Greenleaf, E. A. (1984). Play as a Consumption Experience: The Roles of Emotion, Performance, and Personality in the Enjoyment of Games. The Journal of Consumer Research, 11(2), 728-739. doi:10.1086/209009

Jean, M. Twenge and Charles IM, (2007), Changes in the Need for Social Approval, 1958-2001. Journal of Research in Personality, 41(2007): 171-189

Karaşar, B., and Öğ̈̈lmüş, S., (2016), Sosyal Onay İhtiyacı Ölçeği: Geçerlik ve Güvenirlik Analizi, Ege Eğitim Dergisi 2016 (17)1:84-104

Laverie D.-A., R.-E. Kleine III and S. Schultz Kleine. (1993), Linking Emotions and Values in Consumption Experiences: An Exploratory Study, Advances in Consumer Research, 20, ed. L. McAlister et M.-L. Rothschild, Provo, Utah, Association for Consumer Research, 70-75

Leite, W. L. ve Beretvas, S. N. (2005). Validation of scores on the Marlowe-Crowne social desirability scale and the balanced inventory of desirable responding. Educational and Psychological Measurement. 65, 140-154.

Miller, R. S. (1995), "On the Nature of Embarrassability: Shyness, Social Evaluation, and Social Skills," Journal of Personality, 63 (June), 315-339.

Moscovici, Serge (1985), "Social Influence and Conformity," in Handbook of Social Psychology, Vol. 2, eds. Gardner Lindzey and Elliot Aronson, New York: Random House, 347-412.

Murray, P. N. (2013). Inside the Consumer Mind How Emotions Influence What We Buy The emotional core of consumer decision-making. Retrieved from https://www.psychologytoday.com/blog/inside-the-consumer-mind/201302/ how-emotionsinfluence-what-we-buy

Perrin-Martinenq D. (2004), The role of brand detachment on the dissolution of the relationship between the consumer and the brand, Journal of Marketing Management, 20, 9/10, pp.10011023.

Schwarz, N., \& Clore, G. L. (2007). Feelings and phenomenal experiences. In E. T. Higgins \& A. W. Kruglanski (Eds.), Social Psychology: Handbook of basic principles (2nd ed., pp. 385-407). New York: Guilford.

Stafford, James E and Benton A. Cocanougher (1977), "Reference Group Theory," in Selected Aspects of Consumer Behavior, Washington, D.C.: Superintendent of Documents, U.S. Government Printing Office, 361-380.

Stafford, James E. (1966), "Effects of Group Influence on Consumer Brand Preferences," Journal of Marketing Research, 3 (February), 68-75.

Thibault De Vergnette. (2016). Pourquoi le Marketing Emotionnel vous rendra Mémorable. https://www.alesiacom.com/dossiers/pourquoi-le-marketing-emotionnel-rendra-memorable 
Wakefield, K. L., \& Baker, J. (1998). Excitement at the mall: determinants and effects on shopping response. Journal of Retailing, 74, 515-539

Walsh, G., A.K. Albrecht, C.F. Hofacker, I. Grant, and I. Takahashi. (2016). Developing and validating a scale of consumer brand embarrassment tendencies. Journal of Business Research 69(3): 1138-1147.

William O. Bearden Richard G. Netemeyer Jesse E. Teel (1989), Measurement of Consumer Susceptibility to Interpersonal Influence, Journal of Consumer Research, Vol. 15, No. 4 (Mar., 1989), pp. 473-481

Xiaobing Song and al, (2017), The effect of embarrassment on preferences for brand conspicuousness: The roles of self-esteem and self-brand connection. Journal of Consumer Psychology (1): 69-83

Zarantonello, L., S. Romani, S. Grappi, and R.P. Bagozzi. (2016). Brand hate. Journal of Product \& Brand Management 25(1): 11-25

Zeki \& Romaya (2008) and Salvatori (2007). The Psychology of Love and Hate in Intimate Relationships.

Sternberg, R.J. 2003. A duplex theory of hate: Development and application to terrorism, massacres, and genocide. Review of General Psychology 7(3): 299-328. 